\title{
Removal of chromium(VI) from aqueous solutions by electrochemical reduction-precipitation
}

\author{
Yisheng $\mathrm{Hu}^{1^{*}}$, Jia Zhu ${ }^{2}$ and Yu Liu ${ }^{3}$ \\ ${ }^{1}$ State Key Laboratory of Oil and Gas Reservoir Geology and Exploitation, Southwest Petroleum \\ University, Chengdu 610500, Sichuan, China \\ ${ }^{2}$ Institute of Safety, Environment Protection and Technical Supervision, PetroChina Southwest Oil \\ and Gasfield Company, Chengdu, China \\ ${ }^{3}$ Central Sichuan Oil and Gas Field, PetroChina Southwest Oil and Gasfield Company, Suining, \\ Sichuan, China \\ *E-mail: huyisheng008@yahoo.com
}

doi: $10.20964 / 2017.12 .12$

Received: 5 October 2016 / Accepted: 17 September 2017 / Published: 12 November 2017

In this work, we investigated the reduction and removal of aqueous $\mathrm{Cr}(\mathrm{VI})$ via electrotreatment in a stirred batch reactor using a low-carbon steel electrode. In addition, the capacity to remove chromium from natural seawater, synthetic seawater and wastewater was also studied. The removal of $\mathrm{Cr}(\mathrm{VI}) \mathrm{was}$ primarily based on the simultaneous reduction of $\mathrm{Cr}(\mathrm{VI})$ to $\mathrm{Cr}(\mathrm{III})$, which then precipitated and formed a $\mathrm{Fe}(\mathrm{OH})_{3} / \mathrm{Cr}(\mathrm{OH})_{3}$ sludge to absorb $\mathrm{Cr}(\mathrm{VI})$. The amount of $\mathrm{Cr}(\mathrm{VI})$ that was adsorbed in the sludge increased to a maximum value of $10 \%$ but decreased to a negligible level as the $\mathrm{Cr}(\mathrm{VI})$ concentration in the solution gradually decreased. The $\mathrm{Cr}(\mathrm{VI})$ concentration was reduced to the discharge limit $(0.5$ $\mathrm{mg} / \mathrm{L})$ in a single process without the addition of other precipitation agents.

Keywords: Cr(VI); Adsorption; Precipitation; Electrochemical; Pollution

\section{$\underline{\text { FULL TEXT }}$}

(C) 2017 The Authors. Published by ESG (www.electrochemsci.org). This article is an open access article distributed under the terms and conditions of the Creative Commons Attribution license (http://creativecommons.org/licenses/by/4.0/). 